\title{
PENGUJIAN NORMA HUKUM KETETAPAN MPR NO. XI/MPR/1998 DALAM HIERARKI PERATURAN PERUNDANG-UNDANGAN
}

\author{
Agus Rasyid Candra Wijaya \\ Fakultas Hukum Universitas Muhammadiyah Sukabumi \\ Jl. R. Syamsudin No. 50, Cikole, Kec. Sukabumi, Kota Sukabumi \\ Email: dsn.agus.rasyid.cw@gmail.com
}

\begin{abstract}
The inclusion of the Indonesian People's Consultative Assembly Provisions in the hierarchy of legislation, as stipulated in Article 7 paragraph (1) of Law No. 12 of 2011 on the Establishment of legislation raises several issues related to the establishment and review of the legislation. The Indonesian People's Consultative Assembly Provision No. XI/MPR/1998 on the Implementation of the State that is clean and free of corruption, collusion and nepotism, is one of these provisions is still valid in the structure of the legal norms of the legislation. The purpose of writing this article is to clarify the direction of legal norms of Indonesian People's Consultative Assembly Provision No. XI/MPR/1998 in testing hierarchy of legislation in the future.
\end{abstract}

Keywords: Indonesian People's Consultative Assembly, Judicial Review, Hierarchy of Legislation.

\begin{abstract}
Abstrak
Dimasukannya Ketetapan MPR dalam hierarki peraturan perundang-undangan, sebagaimana diatur dalam Pasal 7 ayat (1) Undang-Undang Nomor 12 Tahun 2011 Tentang Pembentukan Peraturan Perundang-undangan menimbulkan beberapa persoalan yang terkait dengan pembentukan dan pengujian peraturan perundangundangan. Ketetapan MPR No. XI/MPR/1998 Tentang Penyelenggaraan Negara yang bersih dan bebas korupsi, kolusi dan nepotisme, merupakan salah satu ketetapan MPR/S yang masih berlaku dalam struktur norma hukum peraturan perundang-undangan. Tujuan penulisan artikel ini adalah untuk memperjelas arah Norma Hukum Ketetapan MPR No. XI/MPR/1998 dalam pengujian hierarki peraturan perundang-undangan kedepan.
\end{abstract}

\section{Kata Kunci : Ketetapan MPR, Pengujian Norma Hukum, Hierarki Peraturan Perundang-Undangan.}

\section{A. Pendahuluan}

\section{Pengertian Pengujian Norma Hukum}

Peraturan perundang - undangan merupakan peraturan tertulis yang memuat norma hukum. Menurut Hans Kelsen, norma hukum adalah aturan, pola atau standar yang perlu diikuti, yang berfungsi: ${ }^{1}$

a. Memerintahkan (Gebeiten);

1 A. Hamid S. Attamimi, Peran Keputusan Presiden RI dalam Penyelenggaraan Pemerintahan Negara, Disertasi, Fakultas Pascasarjana Universitas Indonesia, Jakarta, 1990, hlm. 302. 

b. Melarang (Verbeiten);
c. Menguasakan (Ermachtigen);
d. Membolehkan (Erlauben), dan
e. Menyimpang dari ketentuan (Derogoereen).

Norma hukum pada hakikatnya juga merupakan unsur pokok dalam peraturan perundangundangan. Dalam kepustakaan Eropa Kontinental, peraturan perundang-undangan atau wet in materiele zin, gesetz in materiellen sinne, mengandung tiga unsur pokok:(i), normahukum; (ii), berlaku keluar; dan (iii), bersifat umum dalam arti luas.Sifat norma hukum dalam peraturan perundang-undangan dapat berupa: perintah, larangan, perizinan, dan pembebasan. ${ }^{2}$

Selanjutnya, menurut Sudikno Mertokusumo, pengertian dari norma hukum adalah:

“...Kaidah hukum lazimnya diartikan sebagai peraturan hidup yang menentukan bagaimana manusia itu seyogianya berprilaku, bersikap didalam masyarakat agar kepentingannya dan kepentingan orang lain terlindungi,atau dalam arti sempitkaidah hukum adalah nilai yang terdapat dalam peraturan konkret."3

Lebih lanjut menurut Sudikno Mertokusumo, dilihat dari fungsinya, maka fungsi kaidah hukum pada hakikatnya berfungsi untuk melindungi kepentingan manusia atau kelompok manusia dan tujuan kaidah hukum tidak lain adalah ketertiban masyarakat. ${ }^{4}$

Pengembangan Hans Nawiasky dalam mengembangkan ajaran Hans Kelsen mengenai teori jenjang norma hukum (stufentheorie), hanya saja Nawiasky menghubungkan teori jenjang norma hukum tersebut dalam negara, sehingga teori Hans Nawiasky lebih dikenal sebagai teori hierarki norma hukum dalam negara (die theorie vom stufenordnung der rechtsnormen). ${ }^{5}$

Mengacu pada teori Hans Kelsen, akan didapati adanya titik persamaan dan perbedaan antara teori Kelsen dengan teori Nawiasky. Titik persamaannya adalah, baik Kelsen maupun Nawiasky sama-sama menyatakan bahwa norma hukum berlapis-lapis dan berjenjang-jenjang membentuk hierarki. Hierarki norma hukum itulah yang membuat norma hukum selalu bersumber dan berdasar pada norma hukum yang lebih tinggi, norma hukum yang lebih tinggi berlaku, bersumber dan berdasar pada norma yang lebih tinggi lagi, sampai pada suatu norma yang tertinggi. yaitunorma dasar (grundnorm), sedangkan titik perbedaan antara teori Kelsen dan teori Nawiasky, Nawiasky menambahkan bahwa norma hukum juga berkelompokkelompok dan pengelompokan norma hukum dalam suatu negara terdiri dari empat kelompok besar, yaitu: ${ }^{6}$

Kelompok I : Staats fundamental norm (Norma Fundamental Negara)

Kelompok II : Staats grund gesetz (Aturan Dasar Negara/ Aturan Pokok Negara)

Kelompok III : Formell gesetz (Undang-undang "formal")

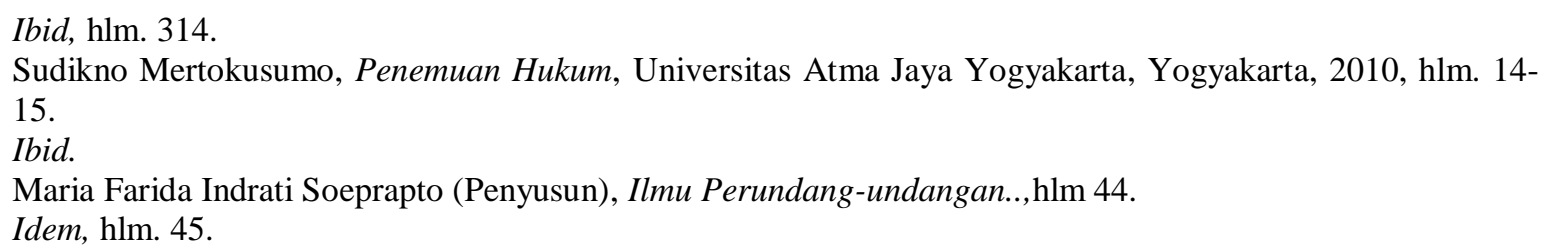


Kelompok IV : Verordnung \& Autonome Satzung (Aturan Pelaksana \& Aturan Otonom)

Kelompok I adalah Staats fundamental norm (Norma Fundamental Negara). Staats fundamental norm adalah norma tertinggi dalam suatu negara. Oleh karena itu, norma ini tidak dibentuk oleh norma yang lebih tinggi lagi. Norma tertinggi ini bersifat pre-supposed atau tidak dapat lagi ditelusuri lebih lanjut dasar berlakunya dan merupakan norma yang menjadi dasar bagi norma-norma yang ada di bawahnya. ${ }^{7}$ Hal senada juga dinyatakan oleh R.M. Ananda B. Kusuma:

"Menurut teori Hans Kelsen, Grundnormadalah sesuatu yang abstrak, diasumsikan (presupposed), tidak tertulis; ia tidak ditetapkan (gesetz).tetapi diasumsikan, tidak termasuk tatanan hukum positif, berada di luar namun menjadi dasar keberlakuan tertinggibagi tatanan hukum positif, sifatnya meta-juristic". 8

Menurut Hans Nawiasky, staats fundamental norm merupakan prasyarat bagi adanya konstitusi atau undang-undang dasar, karena isi staats fundamental norm adalah norma yang merupakan dasar bagi pembentukan konstitusi atau undang-undang dasar tersebut. ${ }^{9}$

Kelompok II adalah Staats grund gesetz (Aturan Dasar Negara/ Aturan Pokok Negara). Norma yang termasuk dalam kelompok ini adalah kelompok norma yang berada langsung di bawah staats fundamental norm. Norma-norma dari kelompok staats grund gesetz ini merupakan aturan-aturan yang masih bersifat pokok dan merupakan aturan-aturan umum yang masih bersifat garis besar, sehingga merupakan norma hukum tunggal. Norma-norma inilah yang nantinya dapat dituangkan dalam suatu dokumen negara yang disebut staats verfassung, atau dapat juga dituangkan dalam beberapa dokumen negara yang tersebar-sebar yang disebut dengan istilah staats grund gesetz. ${ }^{10}$

Staats grund gesetz meliputi hal-hal mengenai pembagian kekuasaan negara di puncak pemerintahan, dan selain itu mengatur juga hubungan antar lembaga-lembaga Negara, serta mengatur hubungan antara negara dengan warga negaranya. ${ }^{11}$

Kelompok III adalah Formell Gesetz (Undang-undang “formal”). Norma-norma hukum didalam kelompok formell gesetz adalah kelompok norma-norma hukum yang berada di bawah staats grund gesetz. Dikatakan formell gesetz (secara harfiah: undang-undang "formal") dikarenakan pembentukan norma ini yang menekankan aspek formal terbentuknya undang-undang. yaitu dibentuk oleh lembaga legislatif.

Kekuasaan legislatif di Indonesia dilakukan oleh DPR bersama Presiden.Setiap produk hukum yang dibentuk oleh dua lembaga yang mempunyai kekuasaan legislatif tersebut dalam UUD 1945 dinamakan undang-undang.Selain undang-undang "formal" sebagaimana diuraikan diatas, juga dijumpai undang-undang “material”. Di Indonesia, memang tidak lazim

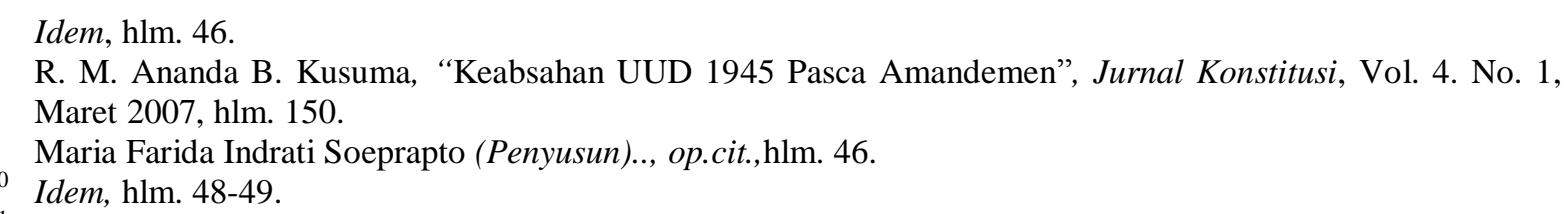


membedakan peristilahan antara undang-undang "formal" dan undang-undang "material", disamping pembedaan tersebut akan dapat menimbulkan kesalahpahaman. Oleh karena itu, lebihbaik digunakan istilah "undang-undang" saja tanpa penambahan atribut "formal". 12

Kelompok IV adalah Verordnung \& Autonome Satzung (Aturan Pelaksana \& Aturan Otonom). Peraturan-peraturan ini berhierarki di bawah undang-undang. Perbedaannya adalah peraturan pelaksanaan bersumber dari kewenangan delegasi, sedangkan peraturan otonom bersumber dari kewenangan atribusi. ${ }^{13}$

Atribusi kewenangan dalam pembentukan peraturan perundang-undangan ialah pemberian kewenenangan membentuk peraturan perundang-undangan yang diberikan oleh undang-undang dasar atau undang-undang kepada suatu lembaga negara atau pemerintah. Sedangkan delegasi kewenangan dalam pembentukan peraturan perundang-undangan ialah pelimpahan kewenangan membentuk peraturan perundang-undangan yang dilakukan oleh peraturan perundang-undangan yang lebih tinggi kepada peraturan perundang-undangan yang lebih rendah, baik pelimpahan dinyatakan dengan tegas maupun tindakan. ${ }^{14}$

Paham konstitusialisme dan supremasi konstitusi menghendaki adanya pembatasan, konsekuensi dari sistem tersebut, yaitu:

a. Penuangan nilai-nilai tertentu yang terdapat dalam masyarakat ke dalam hukum positif, dengan cara membentuk konstitusi tertulis. Maksud untuk memberikan dasardasar serta pengertian hukum bagi nilai-nilai tersebut.

b. Memberikan sifat "rigid" terhadap konstitusi. Konstitusi dianggap merupakan perwujudan dari hukum tertinggi. Artinya kaidah-kaidah konstitusi mempunyai kedudukan lebih tinggi dari kaidah hukum positif lainnya. Dalam tahap ini, konstitusi "mengendalikan" kekuasaan legislatif sedemikian rupa sehingga badan legislatif hanya dapat mengubah konstitusi atau undang-undang dasar itu melalui cara-cara khusus.

c. Menciptakan lembaga atau sistem yang mampu melindungi kaidah-kaidah konstitusi agar tidak dilanggar atau disimpangi baik dalam bentuk peraturan perudangundangan maupun dalam bentuk tindakan-tindakan pemerintah lainnya. ${ }^{15}$

Dalam melindungi kaidah-kaidah konstitusi itu, terdapat berbagai sistem atau tatacara yang ditempuh. Cappelletti membedakan dua sistem pengawasan yang lazim dilakukan, yaitu pengawasan secara politik dan pengawasan secara yudisial. ${ }^{16}$ Baik pengawasan secara politik ataupun pengawasan secara yudisial dilakukan dengan cara menilai atau menguji (review), apakah suatu undang-undang atau peraturan perundang-udangan lainnya atau tindakan pemerintah yang ada atau akan diadakan, bertentangan atau tidak dengan ketentuan-ketentuan konstitusi atau ketentuan yang dinilai. Wewenang menilai tersebut dalam kepustakaan lazim

12 Idem, hlm. 52.

Idem, hlm. 55-56.

Ibid,

15 Rosjidi Ranggawidjaja dan Indra Perwira, Perkembangan Hak Menguji Material Di Indonesia, Cita Bhakti Akademika, Bandung, 1996, hlm 1-2.

16 Idem, hlm 2-3. 
disebut sebagai: "hak menguji" (toetsingsrecht). ${ }^{17}$

Hak menguji untuk melakukan pengujian material diartikan sebagai wewenang untuk menilai, apakah isi peraturan perundang-undangan sesuai atau bertentangan dengan konstitusi atau peraturan perundang-undangan yang lebih tinggi derajatnya. Dengan demikian, pengujian berkenaan dengan isi peraturan perundang-undangan dalam hubungannya dengan peraturan perundang-undangan yang lebih tinggi.Adanya tata urutan atau hierarki peraturan perundang-undangan dalam suatu tata hukum itu sejalan dengan apa yang dikemukakan Hans Kelsen, sebagai hierarchy of norms(stufenbau des recht). Dalam hal ini Kelsen menyatakan :

"... the legal order,.. is therefore not a system of norms coordinated to each other, standing, so to speak, side by side on the same level, but a hierarchy of different levels of norm". ${ }^{18}$

Jadi suatu tata hukum bukan merupakan suatu sistem kaidah-kaidah hukum yang berhubungan satu sama lain dalam kedudukan yang sederajat, melainkan merupakan hierarki dari kaidah-kaidah yang berbeda derajatnya. Menurut teori hierarki itu, peraturan perundangundangan yang lebih rendah tidak boleh bertentangan dengan dengan peraturan perundangundangan yang lebih tinggi derajatnya. Apabila terjadi pertentangan diantara keduanya, maka peraturan perundang-undanganyang lebih rendah derajatnya dapat dibatalkan (voidable). ${ }^{19}$

Pengujian secara terminologi bahasa terdiri dari kata "pengujian" dan "peraturan perundang-undangan". Pengujian berasal dari akar kata "uji" yang memiliki arti percobaan untuk mengetahui mutu sesuatu, sehingga "pengujian" diartikan sebagai proses, cara, perbuatan, menguji. ${ }^{20}$ Sedangkan peraturan perundang-undangan adalah peraturan tertulis yang memuat norma hukum yang mengikat secara umum dan dibentuk atau ditetapkan oleh lembaga negara atau pejabat yang berwenang melalui prosedur yang ditetapkan dalam peraturan perundang-undangan. ${ }^{21}$

Pengujian peraturan perundang-undangan dapat diartikan sebagai proses untuk menguji peraturan tertulis baik yang dibentuk oleh lembaga negara maupun pejabat yang berwenang yang memiliki kekuatan hukum mengikat secara umum. Oleh karena itu, pengujian peraturan perundang-undangan yang diartikan sebagai suatu proses untuk menguji, akan berkaitan dengan "siapa" (subyek) dan "apa" (obyek) ${ }^{22}$ dalam proses pengujian peraturan perundang-

17 Ibid.

18 Hans Kelsen, General Theory of Law and State, translated by Anders Wedberg, Russell \&Russell, New York, 1973, hal 124; Dalam buku Rosjidi Ranggawidjaja dan Indra Perwira, Perkembangan Hak Menguji,. ibid.

19 Rosjidi Ranggawidjaja dan Indara Perwira, Perkembangan Hak,op, cit., hlm. 5.

20 Departemen Pendidikan dan Kebudayaan RI, Kamus Besar Bahasa Indonesia, Balai Pustaka, Jakarta, 1996, hlm. 1096 - 1097.

21 Pasal 1 ayat (2) Undang-Undang Nomor 12 Tahun 2011 Tentang Pembentukan Peraturan Perundangundangan.

22 Subyek dan obyek pengujian telah berkembang dalam perdebatan akademis, politis dan normatif, seperti di BPUPK pada waktu penyusunan rancangan UUD 1945, pembahasan RUU kekuasaan kehakiman tahun 1970, penyusunan Rantap MPR No. III/MPR/2000 dan pada waktu Perubahan Ketiga UUD 1945. Sebelumnya secara akademis dapat disimak perdebatan dalam seminar Hukum Nasional yang diselenggarakan tanggal 27 -30 Desember 1968 di Semarang terdapat lima pendapat ketika harus menjawab kedua pertanyaan yaitu, 
undangan.

\section{Ketetapan MPR Dalam Hierarki Peraturan Perundang-undangan}

Hierarki peraturan perundang-undangan dalam Undang-Undang Nomor 12 Tahun 2011 memasukan Ketetapan MPR dalam susunan jenis dan hierarki peraturan peraturan perundangundangan. Menurut Pasal 7 ayat (1), hierarki sebagai berikut:

a. Undang-Undang Dasar Tahun 1945;

b. Ketetapan Majelis Permusyawaratan Rakyat;

c. Undang-Undang / Peraturan Pemerintah Pengganti Undang-Undang;

d. Peraturan Pemerintah;

e. Peraturan Presiden;

f. Peraturan Daerah Provinsi; dan

g. Peraturan Daerah Kabupaten / Kota.

Penjelasan Pasal 7 Ayat (1) Huruf b Undang-Undang Nomor. 12 Tahun 2011 tentang Pembentukan Peraturan Perundang-undangan, yang dimaksud dengan "Ketetapan Majelis Permusyawaratan Rakyat Sementara dan Ketetapan Majelis Permusyawaratan Rakyat yang masih berlaku sebagaimana dimaksud dalam Pasal 2 dan Pasal 4 Ketetapan Majelis Permusyawaratan Rakyat Republik Indonesia Nomor : I/MPR/2003 Tentang Peninjauan Terhadap Materi dan Status Hukum Ketetapan Majelis Permusyawaratan Rakyat Sementara dan Ketetapan Majelis Permusyawaratan Rakyat tahun 1960 sampai dengan tahun 2002, tanggal 7 Agustus 2003”.

Masuknya Ketetapan MPR dalam hierarki peraturan perundang-undangan menimbulkan beberapa tanggapan dari kalangan praktisi hukum maupun ahli hukum dibidang ilmu peraturan perudang-undangan. Berikut alasan dimasukannya Ketetapan MPR dalam hierarki peraturan perundang-undangan, menurut Wakil Ketua MPR RI Harjriyanto Y. Thohari :

“... Ketetapan MPR/S dan Ketetapan MPR RI merupakan khazanah ketatanegaraan yang sangat kaya dan penting, setelah terbitnya Ketatapan MPR No.I/MPR/2003 tentang Peninjauan terhadap Materi dan Status Hukum Ketetapan MPRS/MPR RI Tahun 19602001, Ketetapan MPR berada disimpang jalan. Undang-Undang Nomor 10 Tahun 2004

lembaga manakah (subyek) yang diberikan kewenangan untuk melakukan pengujian?, dan meliputi peraturan perundang-undangan mana (obyek) saja yang boleh diuji ? kelima pendapat tersebut adalah: a) wewenang untuk melakukan pengujian diserahkan kepada Mahkamah Agung dengan alternatif obyeknya, (1) TAP MPRS, UU dan peraturan perundang-undangan dibawahnya, (2) terbatas UU dan peraturan perundangundangan dibawahnya, (3)terbatas pada peraturan perundang-undangan dibawah UU; b) Wewenang untuk melakukan pengujian hanya ada pada MPR; c) harus diatur secara tegas dalam dalam UUD atau setidaktidaknya Ketetapan MPR untuk menunjuk organ yang diberikan kewenangan untuk melakukan pengujian; d) Kewenangan diberikan kepada hakim; e) Perlu adanya TAP MPR yang menunjuk MA agar diberikan kewenangan untuk menilai dan menyatakan pendapatnya apakah ketetapan yang bersangkutan bertentangan dengan Pembukaan dan batang tubuh UUD 1945. Lihat Sri Soemantri Martosoewignjo dan Bintan R. Saragih, Ketatanegaraan Indonesia dalam Kehidupan Politik Indonesia 30 Tahun Kembali ke UUD 1945, Pustaka Sinar Harapan, Jakarta, 1993, hlm. 225-226. Lihat lembaga Pembinaan Hukum Nasional, Seminar Hukum Nasional II, Tahun 1968, jilid I Umum, hlm. 110-111 . Lihat Zainal Arifin Hoesein, Pengujian Peraturan Perundang-undangan Menurut Konstitusi Indonesia- Studi Tentang Perkembangan Pengaturan dan Pelaksanaannya oleh Mahkamah Agung RI Kurun Waktu 1970-2003, Disertasi Program Pascasarjana Universitas Indonesia, Jakarta, 2006, hlm.53. 
tentang Pembentukan Peraturan Perundang-undangan tidak lagi menempatkan Ketetapan MPR dalam jenis dan hierarki peraturan perundang-undangan dan Ketetapan MPR yang masih berlaku tersebut keberadaannya tidak lagi diakui, bahkan juga oleh Pemerintah dan DPR sendiri. Jangankan ketetapan tersebut dipergunakan sebagai rujukan oleh lembagalembaga negara, bahkan dilirik sebelahmata pun tidak.Pemerintah dan DPR malah cenderung mengabaikan Ketetapan MPR yang masih berlaku tersebut baik dalam proses pembentukan undang-undang maupun dalam perumusan kebijakan negara. UU No. 10 Tahun 2004 saya rasa telah mengandung kesalahan yang sangat fatal. Kini UU No. 10 tahun 2004 telah direvisi menjadi UU No. 12 tahun 2011,dalam undang-undang terbaru hasil revisi ini Ketetapan MPR/S kembali dicantumkan dalam tata urutan peraturan perundang-undangan Indonesia, ini berarti Ketetapan MPR kembali didudukan dalam posisinya yang benar dalam sistem hukum di Indonesia. Implikasinya sungguh sangat besar dan signifikan, Ketetapan MPR kembali menjadi sumber hukum formal dan material dan Ketetapan MPR harus kembali menjadi rujukan atau salah satu rujukan selain UUD 1945 bukan hanya dalam pembentukan perundang-undangan, melainkan juga dalam pembentukan kebijakan-kebijakan publik lainnya. DPR dan Pemerintah mutlak harus memperhatikan ketetapan-ketetapan MPR yang masih berlaku, bahkan merujuk kepadanya dalam pembentukan undang-undang dan peraturan perundang-undangan di bawahnya". 23

Ketua Pansus Rancangan Undang-Undang 12 Tahun 2011 Sutjipto memaparkan:

“...ada beberapa perubahan penting dalam RUU (UU No. 12 Tahun 2011) ini dibanding Undang-Undang Nomor 10 Tahun 2004. Salah satunya adalah dimasukkannya kembali Ketetapan MPR (TAP MPR) ke dalam hierarki peraturan perundang-undangan. Sebelumnya, Undang-Undang Nomor 10 Tahun 2004, telah mengeluarkan TAP MPR dari hierarki.Dicantumkannya kembali TAP MPR ke dalam hierarki, sebagai konsekuensi karena masih banyak TAP MPR yang masih berlaku.Sehingga, dengan masuknya kembali ke dalam hierarki, secara hukum kekuatannya lebih kuat dibanding sebelumnya". 24

\section{B. Pembahasan}

\section{Materi Muatan Ketetapan MPR}

Apabila ditinjau dari segi sifat isinya, Ketetapan MPR/S dapat digolongkan menjadi:

1. Ketetapan yang bersifat mengatur. Ketetapan ini tepat kalau digolongkan sebagai salah satu bentuk/ jenis peraturan perundang-undangan seperti dimaksudkan Ketetapan Nomor XX/MPRS/1966; misalnya, Ketetapan MPR tentang referendum.

2. Ketetapan yang bersifat "penetapan/ beschikking". Misalnya, ketetapan tentang pengangkatan Presiden dan Wakil Presiden, dan tentang GBHN.

3. Ketetapan yang bersifat deklaratur, misalnya ketetapan tentang Pedoman Penghayatan dan Pengamalan Pancasila. ${ }^{25}$

23 http://www.mpr.go.id/files/pdf/2011/11/14/ eksistensi-ketetapan-mpr-pasca-uu-no-12-tahun-20111321247847.pdf, [18/03/2013].

24 http://www.hukumonline.com/berita/baca/lt4e29a86c799c4/hierarki-peraturan-peruu-berubah-, [18/03/2013].

25 Ibid. 
Dalam perkembangannya, disamping materi yang dirumuskan dalam Ketetapan MPR/S tersebut diatas, terdapat pula materi-materi yang lebih bervariasi sebagai berikut:

a. Ketetapan MPR/S yang bersifat deklaratur;

b. Ketetapan MPR/S yang bersifat rekomendasi;

c. Ketetapan MPR/S yang bersifat perundang-undangan yang berlaku mengikat umum. $^{26}$

Dalam kaitan hal diatas, A. Hamid S. Attamimi mengemukakan bahwa:

"Munculnya pengelompokan muatan Ketetapan MPR/S tanpa identifikasi kedudukan MPR lebih dahulu akan menimbulkan kerancuan dan salah paham. MPR harus dikategorikan sebagai badan pembentuk hukum dasar tertulis (konstituante), lembaga yang menetapkan garis-garis besar daripada haluan negara, serta lembaga yang memilih dan mengangkat Presiden dan atau Wakil Presiden. Dari pengkategorian ini akan dihasilkan peringkat norma yang berbeda". ${ }^{27}$

Materi muatan Ketetapan MPR apabila ditinjau dari asas dalam ilmu hukum bahwa isi Ketetapan MPR tidak dapat dan tidak boleh bertentangan dengan dengan UUD 1945.Namun, jika dilihat dari contoh-contoh dan pengelompokan diatas,Bagir Manan berpendapat bahwa, pada dasarnya MPR dapat menetapkan segala jenis materi muatan.Hal ini nampaknya kembali pada dasar pemikiran bahwa MPR mempunyai kekuasaan yang tak terbatas. ${ }^{28}$

Dari materi muatan Ketetapan MPR yang sudah di jelaskan diatas, maka selanjutnya istilah yuridis Ketetapan MPR dapat ditemukan dalam :

1. Ketetapan MPR Nomor II/MPR/1999 tentang Peraturan Tata Tertib Majelis Permusyawaratan Rakyat Republik Indonesia, Pasal 90 ayat (2) yang mengkonstruksi pengertian Ketetapan MPR sebagai "putusan Majelis yang mempunyai kekuatan hukum mengikat keluar dan kedalam Majelis".

2. Ketetapan MPR Nomor II/MPR/2000 tentang Perubahan Kedua Atas Ketetapan Majelis Permusyawaratan Rakyat Republik Indonesia Nomor II/MPR/1999 tentang Peraturan Tata Tertib Majelis Permusyawaratan Rakyat Republik Indonesia. Berdasarkan hasil penelusuran terhadap Pasal 90 ayat (3) Ketetapan MPR Nomor II/MPR/2000, pengertian "Ketetapan MPR" diformulasikan sebagai berikut:

a. Berisi arah kebijakan penyelenggara negara;

b. Berisi rekomendasi Majelis kepada Presiden dan lembaga tinggi negara tertentu lainnya mengenai pelaksanaan putusan Majelis yang harus dilaporkan pelaksanaannya dalam Sidang Tahunan berikutnya;

c. Mempunyai kekuatan hukum mengikat keluar dan kedalam Majelis;

d. Menggunakan nomor putusan Majelis.

26 Jimly Asshiddiqie. Laporan Penelitian "Tinjauan Terhadap Materi dan Status Hukum Ketetapan MPR/S RI 1960-2002”, Sekertariat Jenderal MPR RI., Jakarta, hlm.8. Lihat Riri Nazriyah, MPR RI Kajian Terhadap Produk... op.cit., hlm.177.

27 A. Hamid S. Attamimi. Peran Keputusan... op.cit., hlm 137.

28 Bagir Manan, Pertumbuhan dan Perkembangan Konstitusi Suatu Negara, Mandar Maju, Bandung, 1995, hlm. 30 . 
Ketetapan MPR Nomor III/MPR/2000 tentang Sumber Hukum dan Tata Urutan Perundang-undangan.Pasal 3 ayat (2) Ketetapan MPR Nomor III/MPR/2000 tentang Sumber Hukum dan Tata Urutan Perundang-undangan pengertian Ketetapan MPR sebagaimana dimaksud dalam pasal ini adalah:

"Ketetapan Majelis Permusyawaratan Rakyat Republik Indonesia merupakan putusan Majelis Permusyawaratan Rakyat sebagai pengemban kedaulatan rakyat yang ditetapkan dalam sidang-sidang Majelis Permusyawaratan Rakyat". ${ }^{29}$

\section{Pengujian Norma Hukum Ketetapan MPR No. XI/MPR/1998 Dalam Hierarki Peraturan Perundang-undangan}

Apabila ditinjau Ketetapan MPR No. XI/MPR/1998 Tentang Penyelenggaraan Negara yang bersih dan bebas korupsi, kolusi dan nepotisme, menurut pendapat pemakalah dasar Ketetapan MPR No. XI/MPR/1998 sudah tidak berlaku, ditinjau dari Pasal 4 yang menyebutkan:

"Upaya pemberantasan korupsi, kolusi, dan nepotisme harus dilakukan secara tegas terhadap siapapun juga, baik pejabat negara, mantan pejabat negara, keluarga, dan kroninya maupun pihak swasta/konglemerat termasuk mantan Presiden Soeharto dengan tetap memperhatikan prinsip praduga tak bersalah dan hak-hak azasi manusia".

Tanggapan terkait dengan Ketetapan MPR tersebut Pemakalah berpendapat, bahwa dari proses hukum kasus mantan Presiden Soeharto baik secara hukum pidana maupun hukum perdata:

Pertama; Proses Hukum Pidana menurut Pasal 77 KUHP: Kewenangan menuntut pidana hapus jika tertuduh meninggal dunia". ${ }^{30}$ Bahwa kematian pelanggar itu menghapuskan hak penuntutan pidana, sebab hukuman itu dituduhkan kepada individu yang melakukan kejahatan, tidak dapat dikenakan kepada misalnya akhli-warisnya. ${ }^{31}$ Dalam perkara korupsi ditentukan apabila tersangka meninggal, maka terhadap barang-barang yang disita, hakim dapat memutuskan perampasan barang-barang tersebut atas tuntutan penuntut umum. (Vide pasal 23 ayat 5 undang-undang Tindak Pidana Korupsi). ${ }^{32}$ Selanjutnya hapusnya pelaksanaan pidana, ditinjau dari sudut penuntut umum berarti hapusnya hak penuntut umum untuk memerintahkan terpidana menjalani pidananya.Ditinjau dari sudut terpidana berarti hapusnya kewajibannya untuk menjalani pidana tersebut. ${ }^{33}$ Menurut Pasal 83 KUHP, hapusnya pelaksanaan pidana ditentukan karena "terpidana meninggal". ${ }^{34}$

29 Widodo Ekatjahjana dan Totok Sudaryanto, Sumber Hukum Tata Negara Formal Di Indonesia Kilas Balik Ketetapan MPR RI No. III/MPR/2000, Perubahan UUD 1945, Ide Permasalahan Kekuasaan Kepala Negara dan Pemerintahan, Maklumat Presiden 28 Mei 2001 dan Ide Dekrit Presiden Abdurahman Wahid, Citra Aditya Bakti, Bandung, 2001, hlm. 42-45.

30 Pasal 77 Kitab Undang-Undang Hukum Pidana.

31 R. Soesilo, Pokok-Pokok Hukum Pidana Peraturan Umum dan Delik-Delik Khusus, Politeia, Bogor, 1974, hlm. 98.

32 S. R. Sianturi, Asas-Asas Hukum Pidana di Indonesia dan Penerapannya, Alumni Ahaem, Jakarta, 1996, hlm 427-428.

33 Idem.hlm. 436.

34 Pasal 83 Kitab Undang-Undang Hukum Pidana. 
Kedua;Proses Hukum Perdata sudah ada putusan Mahkamah Agung Nomor 2896 K/Pdt/2009 tertanggal 28 Oktober 2010, mendiang Soeharto sebagai Tergugat I dan Yayasan Beasiswa Supersemar sebagai Tergugat II dan telah memiliki kekuatan hukum tetap atas putusan dari pengadilan.

\section{Penutup}

Apabila ditinjau Ketetapan MPR No. XI/MPR/1998 Tentang Penyelenggaraan Negara yang bersih dan bebas korupsi, kolusi dan nepotisme, sampai terlaksananya seluruh ketentuan dalam ketetapan tersebut dan sekarang telah terbentuk UU tentang Pemberatasan Tindak Pidana Korupsi, meskipun masih ada aspek yang terkait dengan mantan Presiden Soeharto, dapat dikatakan Ketetapan MPR ini sudah tidak berlaku, Sehingga Kedepan Ketetapan MPR No.XI/MPR/1998 Tentang Penyelenggaraan Negara yang bersih dan bebas korupsi, kolusi dan nepotisme perlu dihapuskan dan tidak masuk dalam ketetapan MPR yang masih berlaku sesuai dengan UU No. 12 Tahun 2011.

\section{Daftar Pustaka}

\section{Buku}

A. Hamid S. Attamimi, Peran Keputusan Presiden RI dalam Penyelenggaraan Pemerintahan Negara, Disertasi, Fakultas Pascasarjana Universitas Indonesia, Jakarta, 1990.

Bagir Manan, Pertumbuhan dan Perkembangan Konstitusi Suatu Negara, Mandar Maju, Bandung, 1995

Departemen Pendidikan dan Kebudayaan RI, Kamus Besar Bahasa Indonesia, Balai Pustaka, Jakarta,1996

Hans Kelsen, General Theory of Law and State, translated by Anders Wedberg, Russell \&Russell, New York, 1973.

Jimly Asshiddiqie. Laporan Penelitian "Tinjauan Terhadap Materi dan Status Hukum Ketetapan MPR/S RI 1960-2002”. Sekertariat Jenderal MPR RI., Jakarta,

Maria Farida Indrati Soeprapto (Penyusun), Ilmu Perundang-undangan.

Rosjidi Ranggawidjaja dan Indra Perwira, Perkembangan Hak Menguji,

R. M. Ananda B. Kusuma, "Keabsahan UUD 1945 Pasca Amandemen”, Jurnal Konstitusi. Vol. 4. No. 1, Maret 2007

Rosjidi Ranggawidjaja dan Indra Perwira, Perkembangan Hak Menguji Material Di Indonesia, Cita Bhakti Akademika, Bandung, 1996.

R. Soesilo, Pokok-Pokok Hukum Pidana Peraturan Umum dan Delik-Delik Khusus, Politeia, Bogor, 1974. 
Sudikno Mertokusumo, Penemuan Hukum, Universitas Atma Jaya Yogyakarta, Yogyakarta, 2010

S. R. Sianturi, Asas-Asas Hukum Pidana di Indonesia dan Penerapannya, Alumni Ahaem, Jakarta, 1996.

Widodo Ekatjahjana dan Totok Sudaryanto, Sumber Hukum Tata Negara Formal Di Indonesia Kilas Balik Ketetapan MPR RI No. III/MPR/2000, Perubahan UUD 1945, Ide Permasalahan Kekuasaan Kepala Negara dan Pemerintahan, Maklumat Presiden 28 Mei 2001 dan Ide Dekrit Presiden Abdurahman Wahid, Citra Aditya Bakti, Bandung, 2001.

Zainal Arifin Hoesein, Pengujian Peraturan Perundang-undangan Menurut Konstitusi Indonesia- Studi Tentang Perkembangan Pengaturan dan Pelaksanaannya oleh Mahkamah Agung RI Kurun Waktu 1970-2003, Disertasi Program Pascasarjana Universitas Indonesia, Jakarta, 2006.

\section{Peraturan Perundang-undangan}

Undang-Undang Nomor 12 Tahun 2011 Tentang Pembentukan Peraturan Perundangundangan

Kitab Undang-Undang Hukum Pidana.

\section{Internet}

http://www.mpr.go.id/files/pdf/2011/11/14/eksistensi-ketetapan-mpr-pasca-uu-no-12-tahun2011-1321247847.pdf, [18/03/2013].

http://www.hukumonline.com/berita/baca/lt4e29a86c799c4/hierarki-peraturan-peruuberubah-, [18/03/2013]. 